https://helda.helsinki.fi

Language crashes and shifting orientations : the construction and negotiation of linguistic value in bilingual school spaces in Finland and Sweden

From, Tuuli

2019-05-04

From , T \& Holm , G 2019 , ' Language crashes and shifting orientations : the construction and negotiation of linguistic value in bilingual school spaces in Finland and Sweden ', Language and Education , vol. 33 , no. 3 , pp. 195-210 . https://doi.org/10.1080/09500782.2018.1514045

http://hdl.handle.net/10138/317094

https://doi.org/10.1080/09500782.2018.1514045

unspecified

acceptedVersion

Downloaded from Helda, University of Helsinki institutional repository.

This is an electronic reprint of the original article.

This reprint may differ from the original in pagination and typographic detail.

Please cite the original version. 


\section{Language crashes and shifting orientations: the construction and negotiation of linguistic value in bilingual school spaces in Finland and Sweden}

This article analyses the construction of linguistic value and recognition of linguistic resources in educational spaces in Finland, where Swedish is the second national language and in Sweden, where Finnish is one of five official minority languages. Drawing on ethnographic methods, critically informed notions of language policy and spatial theorization, we argue that linguistic hierarchies created through language and education policies manifest themselves in the discursive construction of linguistic value in the everyday educational spaces. In Finland, the strong societal and political status of Swedish and the monolingual school institutions enable the recognition of language as a right and a resource but potentially present linguistic diversity as a problem within those spaces. In Sweden, the historical traces of a problem orientation towards Finnish language remain, despite the aimed improvements in educational language rights and the shifting orientation on Finnish being recognized as a resource in the market-oriented educational system. Pupils in both countries mostly considered language as a communicative resource in their everyday social spaces but the negotiation of the societal value of language and bilingualism was rather controversial. Discussing linguistic disadvantage in relation to educational spaces will bring new perspectives to language and minority policies in linguistically diverse societies.

Keywords: Ethnography, Language policy and planning, Finnish, Swedish, Minority language

\section{Introduction}

The role of language and language policies in constructing the unifying narratives of modern nation-states is indisputable (Anderson, 2006; Gal, 2010), and schooling has been a central arena for reproducing those narratives of citizenship, cultural identity and linguistic belonging (Heller, 2011; Rajander, 2010). National language policies still maintain their role in the battles of control, differentiation and representation and 
schools, as public spaces, play a significant role as venues for the battles, where language ideologies of the nation-states are being turned into educational practice (cf. Shohamy, 2006). Richard Ruiz (1984) has presented three orientations, i.e. rationalities or dispositions towards languages and their role in society emerging in language policy and planning, these being language as a problem, as a right and as a resource. By determining what is thinkable about language in society, the orientations constitute the framework in which the value of language is shaped and according to which language is governed in school space (cf. Manan, David \& Dumanig, 2016).

This article focuses on the construction of linguistic value and the recognition of linguistic resources in educational systems as a social, political and a spatial process. Our analysis focuses on the construction of linguistic value in bilingual school spaces of two neighbouring countries with an intertwined history, Finland and Sweden, and more specifically the educational spaces of Swedish in Finland and Finnish in Sweden. The construction of linguistic value is conceptualized and analysed by looking at language as a resource, whose value is recognized differently in different educational spaces. Blommaert, Collins and Slembrouck (2005) articulate the connection between language and space through the contextuality of linguistic resources. The calculations of linguistic value vary in different national and educational spaces and the positioning of the speakers is negotiated in terms of their linguistic resources. (Blommaert et al. 2005.) This study is informed by a broad notion of the term language policy, which considers it consisting not only of language planning and management, but also of language ideologies and language practices (Spolsky, 2004; Shohamy, 2006). We then view these dimensions of language policy through a spatial lens, as participating in the construction of discursive and material spaces of education. We understand space as continuously 
reconstructed within the material conditions, institutional practices and social hierarchies of the school (cf. Gordon, Holland \& Lahelma 2000; Hadi-Tabassum, 2006).

The aim of the spatially informed ethnographic approach is to investigate school spaces as sites for linguistic power struggles and the recognition of linguistic resources. While identifying language policies as mechanisms of power, also the potential of language policy agents in shaping and resisting those discourses and practices should be considered (cf. Hornberger \& Johnson, 2010; Johnson, 2011; McCarty, 2015). We have looked at everyday life in a co-located school in Finland, where Finnish- and Swedishspeaking monolingual schools share the same school building, as well as in Sweden, in an institutionally bilingual Sweden-Finnish school. Our focus on school spaces is framed by the following questions: How is the value of language constructed in the interplay of policy and educational practices and discourses in the school space? How are the speakers positioned in terms of their linguistic resources?

\section{Finnish and Swedish in educational spaces of Finland and Sweden}

The multi-sited language political and ideological discourses cannot be separated from historical developments. Despite the intertwined histories of Finland and Sweden, they might be described as different in terms their contemporary language policies. (Halonen, Ihalainen \& Saarinen, 2015.) Since Finnish independence in 1917 and the establishment of the Language Act in 1922, Swedish and Finnish have shared the status of official national languages in Finland'. These days Swedish is the mother tongue for

In addition to the two national languages, the Finnish Language Act (2003:423) does not define other languages historically spoken in Finland, such as Sami and Romani, as official minority languages. 
5.3 percent and Finnish for 88.7 percent of the population (OSF, 2016). The legislation provides strong cultural and political autonomy for the Swedish-speaking Finns, whose position in Finnish society is politically established and dates back to the era when Finland was a part of the Swedish kingdom, until the year 1809. The Swedish language maintained its central position in Finland even during the following hundred years under Russian rule, despite the national movement of the $19^{\text {th }}$ century, which promoted the Finnish language as a means for nation-building. (Henning-Lindblom, 2012; Latomaa \& Nuolijärvi, 2005). Even today the Swedish-speaking Finns are well represented as a minority group in Finnish society in terms of cultural capital and political influence (cf. Henning-Lindblom, 2012; McRae, 2007; Saarela \& Finnäs, 2004.). However, particularly in recent years and after the rise of nationalist tendencies within the political field in Finland, issues related to Swedish as the second national language and Swedish-speaking institutions have remained a source of controversy within language political debates, despite bilingualism being a constitutive principle of the nation since Finnish independence (Ihalainen \& Saarinen, 2015; Hult \& Pietikäinen, 2014).

In Sweden, the status and image of Finnish language is often perceived as being linked to work-related migration to industrial urban areas during the post-war decades, even if the territorialisation of Finns in Sweden has taken place for a thousand years (cf. Lainio, 2015; Halonen, Ihalainen \& Saarinen, 2015). Today, those with a Finnish background form an estimated seven percent of the entire population in Sweden. (cf. Henning-Lindblom, 2012.) $)^{2}$ The construction of the Swedish welfare state from the

${ }_{2}^{2}$ This estimate varies, since Sweden does not compile similar statistics concerning spoken languages of the nation (ref. Henning-Lindblom, 2012). 
1930's until the early 1990's gave rise to monolingualism as a national norm and resulted in assimilatory policies with regard to languages considered as immigrant languages. Starting from the 1970's, assimilation as a means for integration was gradually replaced with more multilingual policies, but the ideological construction of Swedish as 'society bearing' (samhällsbärande) has remained. (Lainio, 2015; Milani, 2007.) In the year 2000, however, Sweden ratified the European Charter for Regional or Minority Languages, through which Finnish, Yiddish, Romani chib, Sami, and Meänkieli were recognised as national minority languages (Council of Europe, 2017). The Swedish Language Act (2009:600)ㄹ, the Act on National Minorities and Minority Languages (2009:724) and the Education Act (2010:800) have aimed to further guarantee the minority's linguistic rights in educational systems (Henning-Lindblom, 2012). However, despite these targeted improvements Sweden has repeatedly received criticism from the Council of Europe, as well as from national minority delegations, for shortcomings in the implementation of language and minority policies, particularly in education. (Council of Europe, 2015; 2017; Huss, 2016; Syrjänen Schaal, 2013.)

Despite the recent tendencies of marketization of educational policies particularly in Sweden, it may still be argued that the values of democracy, participation and equal access are to some extent maintained as the ideals of Nordic educational systems (cf. Beach, 2017; Lundahl, Erixon Arreman, Holm \& Lundström, 2013). In Finland and Sweden, the positions of Swedish and Finnish in education are being constantly negotiated in public and policy discourses on language (Boyd \& Palviainen, 2015; From \& Sahlström, 2017; Lainio, 2015). In Finland, the education for the

${ }^{3}$ The Language Act (2009:600) also confirmed the position of Swedish as the principal language of Sweden. 
Swedish-speaking children is provided in monolingual Swedish-medium public school institutions, since the Basic Education Act (628/1998) requires the education to be organized separately for both language groups. However, learning Swedish is compulsory for all pupils in Finnish-medium schools and vice versa, except for the monolingually Swedish Åland Islands, ${ }^{4}$ where learning Finnish is voluntary. (cf. Engman, 1995; Ihalainen \& Saarinen, 2015; Palviainen, 2011.) Due to the legislation, there are no bilingual schools with instruction in both national languages in Finland. The Strategy for the National Languages declares that "a Swedish-language school cannot act as a language school because its task is to be an institution that passes on and creates Swedish language in Finland.” (Tallroth, 2012, p. 14). Despite the recent, economy-driven changes the Swedish-speaking school network has been subject to in various municipalities in Finland, such as the merging of small village schools into larger units, the spatial autonomy in education is maintained through language and education policy. Some separate Finnish- and Swedish-speaking schools are co-located in the same school building but even this kind of co-operation, as well as the initiatives for actual bilingual schools with instruction in two languages, has been a heated topic of debate and often in the public debate considered as a threatening the spatial autonomy of Swedish in Finland. (From \& Sahlström, 2017; Kajander, Alanen, Dufva \& Kotkavuori, 2015; Boyd \& Palviainen, 2015.)

In Sweden, children with a Finnish background are, according to the legislation, entitled to use and develop their language and cultural identity in education. In

4 The Åland Islands are an autonomous region located in the Baltic Sea between Finland and Sweden. They received their special status when Finland gained independence from Russia in 1917 (Wahlbeck, 2013). 
comprehensive education, the children belonging to national minorities have an enhanced right to mother tongue instruction, even without an elementary language proficiency, and even if the language is not used at home in daily interaction. (Hult, 2004; Language Council of Sweden, 2016; Swedish National Agency for Education, 2015.) However, only the legislative minimum amount of mother tongue instruction in Finnish is organised within the public school system and Finnish-speaking instruction is for the most part provided in bilingual independent schools outside the public school system. Independent schools are owned by private organisations but funded with public money from the local municipality, based on the number of pupils they have enrolled. They are not allowed to charge fees or require admission examinations but are allowed to accept private donations. (cf. Cabau, 2014; Gynne \& Bagga-Gupta, 2013.) The independent bilingual schools apply the Swedish national curriculum and function under the school legislation, according to which they have to have at least fifty percent of their teaching in Swedish and gradually increase the proportion of Swedish as the language of instruction towards the end of basic education (The Swedish School Ordinance, 2011; Swedish National Agency for Education, 2015). The shortcomings in the implementation of the legislation, such as availability of mother tongue instruction, bilingual education and the inadequate number of minority language teachers, have been pointed out by the national authority responsible for monitoring the development of minority policies in Sweden as well as researchers specialised in language and minority policies (Lainio, 2017; County Administrative Board of Stockholm \& Sami

\footnotetext{
However, as pointed out by Lundahl and others (2013), the emergence of independent schools is not the only aspect of marketization of Swedish education but competition has been established between all elementary schools at a municipal level.
} 
Parliament, 2016). Taken together, the educational spaces for Finnish in Sweden are more restricted compared to the ones for Swedish in Finland in terms of the educational systems they are constructed within as well as the realization of the language policies that are supposed to create those spaces.

\section{Ethnographic context and research data}

In this article, we apply a cross-cultural ethnographical approach, in which the different premises both in policies and practices are taken as a starting point for the ethnographic analysis. Elina Lahelma and Tuula Gordon (2010) define the aim of cross-cultural reflection as increasing theoretical understanding through the analysis of cultural variation and focusing not only on differences but also finding similar patterns.

The ethnographic fieldwork for this study was conducted in two different bilingual school spaces in Finland and in Sweden during the school year 2014-2015 by the first author of this article. The fieldwork was carried out in one monolingual Swedish- and one Finnish-speaking public primary school (grades 1-6) that were functioning as separate units but co-located in the same building in Finland and in a bilingual Sweden-Finnish independent school in Sweden (grades 1-9). The fieldwork consisted of participatory observations, participatory photography and photo-elicitation interviews with pupils, ${ }^{6}$ and interviews with the educators. Participant observations focused on formal and informal activities of the schools, i.e. classes, breaks on the

${ }^{6}$ In this voluntary task given by the researcher for the purposes of this study, pupils received instructions to freely photograph their school life under the title "Everyday life in the co-located school/ SwedenFinnish school" and the happenings and places they found important or central. Before the photoelicitation interview they were asked to provide a short description of the printed photos they particularly wanted to discuss. 
school yard, mutual assemblies and festivities, formal staff meetings as well as informal interactions among staff. The ethnographic fieldwork was carried out during a ten-week period in both schools in Finland and a seven-week period in the Finnish school in Sweden. At the end of the following semester, a two-week period was used for some more observations and discussions with the participants. During the school year, 70 days were spent in the field schools altogether. In each school there was one focal class ${ }^{7}$ that was followed during the formal school days. Depending on the various class and teaching arrangements in each school, the focus classes consisted of fourth-, fifth- and sixth-grade pupils in elementary education. A majority of the pupils in the focus classes also took part in a participatory photography project, in which they were asked to photograph their daily lives at school and discuss these photos with the researcher in a photo-elicitation interview. 35 pupils took part in the interviews and two merely wrote descriptions of the photos they had taken. The semi-structured interviews with principals (4), teachers (15) and school assistants (4) were conducted at the end of the first field periods. The interviews included topics concerning everyday practices in a bilingual school space as well as questions related to language in education more generally. Particular consideration was paid to the ethical aspects of ethnography during the fieldwork and data analysis, such as the confidentiality of participation, the representation of participants' voices through translated interviews and the linguistic power relations between the researcher and the participants in a context, where several

\footnotetext{
We primarily contacted the fifth-grade teachers in each school since this grade seemed appropriate in terms of variation in the curriculum. In the Swedish-speaking school in Finland the fifth-grade pupils were studying in the same group with the sixth-grade pupils, whereas in the Sweden-Finnish school the fifth-graders shared the classroom with fourth-graders. We then included the whole class in the study.
} 
languages were used for research purposes. As Canagarajah \& Stanley (2015) put forth, in writing about ethnography, the subjects exist only through the voices of the researcher and thus, there is a particular risk of losing the complexity by essentialising and generalising the findings to fit the theoretical constructs of the researcher. ${ }^{8}$

\section{Reflections of cultural value and commodification of language in education}

In this section, we look at how the value of language was constructed in the interplay of language policy discourse and educational practices in school spaces. We aim to illustrate, how the educational spaces that are constructed through different policies that position language in educational systems highlight different value orientations to language, in other words, consider language as a right, a resource or a problem (Ruiz, 1984). Moreover, Ruiz (ibid.) separates between intrinsic value, related to for example identity construction and cultural reproduction, and extrinsic value of language, which refers to such areas as media, national security or diplomacy.

In Finland, an understanding of Swedish language having a central role in the historical development of Finnish society was typically recognised among the staff in both the Swedish-speaking as well as the Finnish-speaking school. This cultural value was also reflected in the arguments for Swedish language's spatial integrity in education in both material and symbolic terms. In co-located schools, the architecture typically provides an environment, which enables maintaining a monolingual Swedish-speaking space, even while sharing the premises with a Finnish-speaking school (From \& Sahlström, 2017). In the following excerpt, the principal of the Swedish-speaking

\footnotetext{
All the names used in this article are pseudonyms.
} 
school ponders the possibilities of a bilingual school or a bilingual administration for both Finnish- and Swedish-speaking schools.

"Since we are a minority and there is a distinct linguistic culture and maybe a cultural difference also in our ways of acting and thinking and the languages are so different that you think from a linguistic perspective initially that they aren't even related to each other's languages, that this already [makes it complicated to consider a bilingual school with a shared administration]." (Interview with the principal in the Swedish-speaking school in Finland, 01/2015, translated from Swedish by the authors)

In her talk the principal attaches Swedish language to a certain linguistic culture and an understanding of cultural and linguistic difference, which in her words implies a certain way of acting and thinking. The Swedish-speaking are referred to as a minority but no explicit language policy connections are made to strengthen the argument of the position of Swedish in the Finnish school system. Instead, maintaining a cultural and linguistic difference between the national languages seems to be valuable in itself and proposes a certain distance between them in educational spaces. However, an understanding of separation on an institutional level as crucial did not exclude the interest for bilingual educational practices between schools. Thus, linguistic diversity in the social spaces of the school per se is not seen as unwanted or problematic but a language policy promoting the separation of the administrative spaces of education in Swedish and Finnish is seen as protecting the cultural value of Swedish in the Finnish nation space.

Among the educators in the Finnish-speaking school, the Swedish language was typically seen as a cultural resource but also as a commodity, as something that can be converted into material resources outside the Swedish-speaking population (cf. Heller, 2010). This also seemed to have an impact on how the position of the national 
languages in the Finnish school system was considered. In the following excerpt, an educator in the Finnish-speaking school in Finland, talks about the benefits of the Swedish language and how she considers the Swedish-speaking schools being too selective if they turn away pupils from Finnish-speaking families interested in language learning. ${ }^{9}$

\begin{abstract}
"There are [Finnish-speaking] parents who have moved to an area with a Swedishspeaking school next to them and they would want to put their kids there and they have been told that it is not possible since it's not the home language, that the school won't accept them. I think it's wrong since why not, in the same way you put your children into an international school in English. I mean they don't know the language but they learn it there. [- - It could also be a certain selling point like learning internationality, that it's not only the Swedish language but you then have the whole Nordic countries, everything, when you learn here that it's not only the small community in this country but it's something else as well." (Interview with a teacher in the Finnish-speaking school in Finland, 01/15, translated from Finnish by the authors)
\end{abstract}

Here, the value of Swedish is created through a potential for internationalisation, which may refer to economic or cultural aspects on a personal or national level (cf. Ruiz, 1984). This illustrates how Swedish language was considered a resource in a similar way to English in international schools, its economic and cultural value being recognised also among the linguistic majority (cf. Rajander, 2010). From this educator's point of view the Swedish language is seen as a path to internationalisation and as a selling point that is considered appealing outside the linguistic minority as well. Respectively, she considers that the Swedish-speaking school could use their linguistic

\footnotetext{
' In the year 2013 the number of pupils in Swedish-speaking primary schools in Finland who had Finnish as their first language was four percent and the number of pupils with some other mother tongue than Swedish or Finnish was five percent (Westerholm, Lindberg \& Oker-Blom, 2014).
} 
resources as an asset for attracting more pupils and further increasing interest in Swedish. In the co-located school, many teachers of the Finnish-speaking school were interested in co-operating with the Swedish-speaking school in terms of sharing linguistic resources. The co-operation was considered as rewarding due to the Swedish language that most of the pupils in the Finnish-speaking school were unfamiliar with. In the Swedish-speaking school, by contrast, most of the pupils already had some proficiency in Finnish language and the co-operation with the neighbouring school did not have a similar instrumental reward. There were many staff members in the Swedishspeaking school who were positive towards the co-operation, but still considered the maintenance of a linguistically safe space as the most important task of the Swedishspeaking school. This also resonates with the policy discourse around Swedish in Finland, articulated in The Strategy for the National Languages, that neglects the role of Swedish-speaking schools as language schools for pupils with other mother tongues than Swedish (Tallroth, 2012). Also Ruiz has pointed out how the speakers of minority languages are sometimes positioned as helping the majority in language learning. (Ruiz, 1984; Hult \& Hornberger, 2016).

In the Sweden-Finnish school in Sweden and particularly among the educators who considered themselves as bilingual, there seemed to be a mutual understanding of the marginal position of Finnish language in the educational spaces of Sweden. The shortcomings in the implementation of the national language and minority policies as well as the market oriented educational system were typically referred to as the main reasons for this. In the following excerpt, the principal of the Sweden-Finnish school in Sweden ponders the teachers' awareness of the historically assimilatory nature of Swedish language policies and how it has affected their own practices in not wanting to control the language use of the pupils in this particular bilingual school. 
"They [the teachers] don't want to silence the child in the same way that the Finnish-speakers have been silenced in the different situations where one was not allowed to use Finnish. One was not allowed to use it during breaks, not in school. One was barely allowed to use it at home [- - ] so I think our teachers are well aware of that and aware of the Swedish language policy having been and still is purely exclusive. (Interview with the principal in the Sweden Finnish school in Sweden, 05/2015, translated from Finnish by the authors)

The past assimilatory orientation towards linguistic diversity and Finnish language as a problem in the Swedish educational context is reflected in the principal's words (cf. Ruiz, 1984). She considers the teachers in the Sweden-Finnish school wanting the make a change as educators in not being willing to restrict the pupils' language use, not wanting to pass on the dis-recognition of the value of Finnish language in Swedish society. This dis-recognition has been societally implemented as policies of spatial marginalisation, through which Finnish language has been silenced in the educational institutions of Sweden. The principal refers to the Swedish legislation being exclusive even today, while not promoting the Finnish language as a right, which can in her words be seen in, for example, the difficulties and restrictions in receiving education in Finnish despite the existing policies.

Another domain, which illustrated the orientations to language appeared to be the position of Finnish language in the present educational system and independent schools in Sweden. In the interviews and informal discussions, the majority of teachers were critical about the achievements of the Swedish language and minority policies and many of them expressed the position of Finnish in the educational context as hopeless, both in terms of mother tongue instruction and bilingual education. However, in the staff meetings of the Sweden Finnish school in Sweden, the cognitive and economic benefits of bilingualism were typically discussed as a potential asset for marketing the school. As Ruiz (1984) suggests, making positive arguments on the economic value of 
language is well-grounded in advancing multilingual education with respect to the current political rationales. The teachers in Sweden articulated this as an aim to construct a particular bilingual profile for the independent school for marketing purposes. In the following field note excerpt from a teachers' meeting in the Sweden Finnish school in Sweden, the value of the Finnish language is articulated in relation to the labour market and reflected upon the improved reputation of the Finnish minority.

The principal starts talking about co-operation with companies. Particularly to the older students it needs to be emphasized that they can apply for jobs in Finland, the job market will expand. [- -] Johanna brings up the improved reputation of the Sweden Finns, "it's in to be a Finn". We have never been this exotic, she adds. The principal agrees that something has happened regarding the reputation and the attitude and it has to be used as an instrument for advertisement, "it's great to be bilingual". (Field notes, the Sweden-Finnish school in Sweden, notes in Finnish, discussion in Swedish)

On the basis of the observations and interviews, it seems that in the position of Finnish in the Swedish society and educational spaces is partly empowered by highlighting the instrumental value of the language as connected to economic capital. Due to the negative, classed representations attached to Finnish language in past decades, this has required a shift in the discourse, which according to Johanna's speech now enables revaluing the language, for example, in relation to the Nordic labour market. This can be conceptualised as a gradual shift from a problem-orientation to viewing Finnish as a resource (Ruiz, 1984). However, it seems that in the market-oriented educational system, the minority language speakers are also required to justify their linguistic rights, such as the right to the protection and promotion of their language (The Swedish Language Act, 2009; Act on National Minorities and Minority Languages, 2009) using a certain discourse, which prioritizes the resource orientation over the orientation drawing on language as a right (cf. Ruiz, ibid.). This also resonates with Tollefson's 
(2013) notion of the rise of global capitalism at the expense of the nation-state in steering language policies, which provides new ways for capitalist principles to enter school spaces and establish them as linguistic marketplaces.

Many teachers in the Sweden-Finnish school had a background other than Finnish but, interestingly, none of these teachers without a Finnish background spoke Finnish themselves and many of them would comment on their lack of linguistic proficiency by stating that Finnish is a difficult language that they had not managed to learn even after working in the school for a significant number of years. The absence of Finnish in the non-Finnish speaking teachers' linguistic repertoire was seen as a problem neither by the teachers themselves nor in the official discourse of the officially bilingual school, but more often became a source of humour, like in the following conversation with Rikard, a non-Finnish-speaking teacher in Sweden-Finnish school.

I apologize for excluding Rikard from the conversation by speaking Finnish with the pupil. He laughs and tells me that there is no need to apologize for that, as after ten years in the school he has gotten used to these situations and has still not managed to learn Finnish. (Field notes, the Sweden-Finnish school in Sweden, notes in Finnish, discussion in Swedish)

According to the Swedish school ordinance (2011:185), the proportion of Swedish in bilingual education increases towards the upper classes of basic education. Therefore, it is basically possible to teach in a bilingual school without being capable in the other official language of instruction. Even though the independent schools could require a bilingual proficiency from their staff, there is a lack of qualified bilingual teachers in Sweden (cf. Cabau, 2014; Syrjänen Schaal, 2013). However, this disinterest of the teachers towards learning Finnish can also be seen as a manifestation of the linguistic power relations, as positioning Swedish as the main academic language and Finnish as something secondary in the linguistic hierarchy of the school. 


\section{Controversial negotiations of pupils' linguistic resources}

In this section we look at how linguistic value is constructed in the social spaces of the field schools and how pupils become positioned in terms of their linguistic resources. In Sweden, bilingualism was present in the physical spaces of the school in several ways, as posters, signs and pupils' work and it was also frequently documented by pupils through their photographs. However, despite the diversity promoted through the linguistic landscapes (cf. Blommaert, 2013; Dressler, 2015), the pupils' discourses of bilingualism and Finnish language during the interviews and observations also reflected de-valuation related to Finnish language in Sweden. In the following excerpt the researcher has returned to the field school for a follow-up visit and is discussing with two girls, now sixth graders, from the class she used to observe during her first visit at the Sweden Finnish school. While talking, the researcher asks the girls to reflect on the decreasing amount of Finnish as the language of instruction, which they bring up during the conversation. The amount of Swedish in bilingual education in Sweden has to be gradually increased towards the upper classes of basic education (The Swedish School Ordinance, 2011). This regulation aims at providing equal possibilities for further studies in Swedish-speaking institutions but also reflects the position of the Finnish language in the social spaces of the school.

I'm spending the break in the front door talking with Senja and Henrika, asking about the news of the class and the new teacher. According to the girls this year everything else than Finnish language is taught in Swedish.

Researcher: is it a good or a bad thing?

Henrika (with irony in her voice, as if I asked a silly question): well pretty good since we live in Sweden

Researcher: could Finnish be of any use?

Henrika: well if someone comes from Finland

Senja: like I didn't know anything when I arrived 
(Field notes, Sweden-Finnish school in Sweden, conversation and notes translated from Finnish)

The gradual shift in the position of Finnish as the academic language of the school is also reflected in how the pupils consider the benefits of Finnish language in the Sweden Finnish school. In Henrika's talk, Swedish language is the most obvious, unquestionable linguistic resource needed in the Swedish nation space. The significance of Finnish, by contrast, manifests in the first phases of integration, such as when Senja arrived in the school from Finland, without knowing any Swedish - or knowing anything about the Swedish society. As Muhonen (2013) has also noted, Finnish is considered a personal benefit rather than having societal value among the Sweden Finnish pupils. In Ruiz's (1984) terms, the pupils in the Sweden Finnish school seemed to consider Finnish being a personal or the school community's resource instead of a national one. Interestingly the pupils rarely talked about bilingualism or the Finnish language as beneficial or valuable inside Swedish society, despite Finnish being the largest national minority language in Sweden. This lack of recognition among pupils was also explicated by some teachers in the interviews. The value of Finnish language was typically either related to being able to communicate with relatives living in Finland or with the non-Swedish-speaking pupils recently arrived from Finland.

In Finland, the number of pupils who are bilingual with Swedish and Finnish varies regionally in the Swedish-speaking schools (cf. Westerholm, Lindberg \& OkerBlom, 2014). In the Swedish-speaking class studied in this project there were only three pupils who came from bilingual families. In the following excerpt, Kia and Selma, two 
bilingual pupils of the Swedish-speaking class, are contemplating the benefits of bilingualism and their position as bilinguals in the rather monolingual Swedish group ${ }^{10}$.

Interviewer: Do you think your position is somehow different since you know both languages, for example compared to those in your class who don't know Finnish? Selma: Well it's good since [...] if for example they [pupils in the other school] start talking something [...] somebody who is a bit worse in Finnish tries to answer and if s/he says something wrong they start to laugh and mock, it's irritating.

Kia: And sometimes they [...] when the girls had a fight with one Finnish-speaker they always came to me and asked if I could like translate.

Interviewer: So a kind of an interpreter?

Kia: Yes.

Selma: It's good that you know Finnish and Swedish, since then you can talk with them and understand what they are saying. (Interview with Kia and Selma, pupils in the Swedish-speaking school in Finland, 01/2015, translated from Finnish by the authors)

In Kia's and Selma's speech the value of bilingualism and competence in Finnish is constructed as a communicative resource in the social space of the school. In a colocated school, both in Swedish- and Finnish-speaking institutions, knowing the language of the neighbouring school seemed to be a local resource for pupils in both schools and the difficulty of communicating with pupils from the other school was often understood as related to a lack of linguistic competence. Language was considered as a resource by the pupils themselves in constructing alternative social spaces of the school, as enabling encounters between the language groups that were most often kept apart in the physical school space.

In Sweden, the value of bilingualism to the pupils often seemed not to be selfevident but a result of rather controversial negotiations of positioning. In the following

\footnotetext{
${ }^{10}$ In accordance with their decision the interview was carried out in Finnish.
} 
excerpt, a non-Finnish-speaking teacher in the Sweden-Finnish school in Sweden is discussing the linguistic juxtapositions she has observed between pupils with different backgrounds and linguistic resources.

We come to talk about Cindy [a pupil in the class observed in the study], who, according to the [non-Finnish-speaking teacher], speaks "fresh Finnish", since she has moved from Finland just in the autumn. The teacher tells me that according to the other pupils she often talks too fast and uses words that the pupils who grew up in Sweden don't understand. To Cindy their Finnish sounds similar to the language Cindy's grandparents use, the teacher continues. She names this controversy as a language crash, "språklig krock" [in Swedish]. (Field notes, Sweden Finnish school in Sweden, 03/2015, translated from Finnish by the authors)

The pupil that the teacher is referring to has newly arrived from Finland and speaks Finnish in a way that is described as "fresh" by the (non-Finnish-speaking) teacher. The freshness of the language in relation to the Finnish that the other pupils in the school are speaking forms a distinction, which is not necessarily a positive one but also leads to alienation among some pupils. The language crash described by the teacher has also been identified by the researcher in some other formal and informal class situations. According to the teacher, the other pupils have difficulties in understanding Cindy, since she speaks quickly and uses words that are not familiar to the children who have grown up in Sweden, whereas the language they use remind Cindy of her grandparents' way of speaking. This can be interpreted as an example of the contextuality of linguistic resources on a national level; Finnish language is tied to the Finnish nation-space, constantly changing and developing in the nation state it is considered to belong to. In the school space in Sweden, "fresh Finnish" is not something that would be recognized as an unambiguous resource, but rather as something deviant from the linguistic norms that take part in defining the legitimate language of the school (cf. Juva \& Holm, 2016). Furthermore, this excerpt is also an 
example of the complexities of positioning subjects in terms of their linguistic resources. Despite Cindy's fresh Finnish, there is no position of a linguistic or cultural authority available for her in the school space. Instead, that position was available for the researcher coming from Finland, who was in many instances seen by the staff and students to bring valuable knowledge of Finnish society, language and up-to-date vocabulary into the school community.

\section{Discussion}

The ethnographic analysis conducted in this study has pointed out how languages are valued or de-valued in different educational spaces and how the national language and education policies as well as the societal statutes of languages manifest in these processes. We have argued that using a spatially informed approach enables an analysis that shed light on the contextuality of linguistic value and illustrates the linguistic hierarchies constructed in educational systems. Thus, linguistic value attributions should be considered in relation to spatial marginalization or the possession of space in educational institutions of nation states. Despite the historical and linguistic confluences and intersections in the construction of Finnish and Swedish nation-spaces, there are clear differences in how language is constructed and recognised as a resource in their educational systems, these differences being shaped by political, historical, cultural and societal conditions. In Finland, the language policies and ideologies of a bilingual nation and two monolingual institutions were constantly being negotiated and at times contested in more or less bilingual everyday life of the co-located Finnish- and Swedish-speaking schools. The rather monolingual norm of the school institutions may be criticized for hampering the recognition of linguistic diversity but one should not underestimate the potential of policy in providing space for minority languages in 
educational systems. From the pupils' perspective, the value of speaking both languages in a co-located school was connected to how it offered ways to shape the social spaces of the school by crossing the institutional language borders (cf. From \& Sahlström, 2017). In Sweden, in a bilingual Sweden-Finnish school, both Finnish and Swedish count as legitimate languages in the formal school space and take part in the construction of linguistic norms accordingly. However, as analyses of the everyday life in the school reveal, the recognition of Finnish and Swedish as resources is framed differently, Finnish being considered as a personal resource, whereas Swedish is presented as an unquestionable linguistic resource for succeeding in the Swedish society. However, while aiming at maintaining educational spaces for Finnish language in the Swedish educational system with an insufficient policy, referring to the instrumental value of language in economic terms seems to be a crucial strategy.

Analysed in the framework proposed by Ruiz (1984), traces of all the presented orientations manifest in school spaces; language as a problem, as a right or finally, and most dominantly, as a resource. In this article we have aimed to look at how the national language and educational policies participate in shaping those articulations in school spaces. In the Finnish context, traces of the resource orientation were reflected in how Swedish was framed as a resource for everyone in the Finnish society and a potential means for parental school choice (see Rajander, 2010 and Kosunen, 2016 for parental school choice and specialized language classes in Finland). In Sweden, the resource rationale seemed to become a measure for marketing the school, which might pose certain problems in terms of educational language rights. When language is recognised as valuable first and foremost in providing access to other material and social resources, questions related to identity and linguistic belonging are more likely to become submerged. Moreover, in marketized educational systems promoting the instrumental 
value of language, societally disadvantaged languages do not have equal possibilities to gain value through being recognized as resources or but are more often viewed as problems to be governed through national language policies (cf. Ruiz, 1984).

The discourse on value attribution through commodification also provokes a concern of individualisation of issues related to language policy. For example, in the data from Sweden, the improved status of Finnish was most often considered as resulting from improvements in individual attitudes of the linguistic majority and consumers on the linguistic markets, rather than resulting from improvements on a policy level. Such a discourse contains a risk of language becoming a depoliticised commodity that is detached from societal power relations, policy-making and weakly connected to human rights but rather to competitiveness and marketability. As Heller (2011) points out, the lack of legitimate language proficiency can in different contexts be understood as a lack of individual competence or merit, not as a fault in realisation of linguistic rights.

Analysing the recognition of linguistic resources in the everyday spaces of education offers new ways of understanding how languages are positioned within educational systems in the Nordic countries and beyond. Moreover, we can see how different spaces constructed and framed through language and educational policy promote or hinder the recognition of language as a right or a resource. In linguistically diverse educational spaces, which in contemporary societies refer more or less to the norm of educational realities, the power relations between languages and the classed intersections enabling or constraining linguistic value should be made visible. As Ingrid Piller (2017) writes, the recognition of language-related disadvantage is a prerequisite for working towards a positive change. 


\section{Acknowledgements}

This research has been supported by NordForsk. We would also like to express our gratitude for the two anonymous reviewers for their insightful comments on the manuscript.

\section{References}

Anderson, B. (2006). Imagined communities. Reflections on the origin and spread of nationalism. London: Verso.

Beach, D. (2017). Whose justice is this! Capitalism, class and education justice and inclusion in the Nordic countries: race, space and class history. Educational Review, 69 (5).620-637.

Blommaert, J. (2013). Ethnography, Superdiversity, and Linguistic Landscapes: Chronicles of Complexity. Bristol, UK: Multilingual Matters.

Blommaert, J., Collins, J. \& Slembrouck, S. (2005). Spaces of multilingualism. Language \& Communication 25. 197-216.

Boyd, S. \& Palviainen, Å. (2015). Building walls or bridges? A language ideological debate about bilingual schools in Finland. In: M. Halonen, P. Ihalainen \& T. Saarinen (Eds.) Language policies in Finland and Sweden. Interdisciplinary and multi-sited comparisons. Bristol: Multilingual matters. Pp. 57-89.

Cabau, B. (2014). Minority language education policy and planning in Sweden. Current Issues in Language Planning, 15:4, 409-425.

Canagarajah, S.\& Stanley, P. (2015). Ethical considerations in language policy research. In: F.M. Hult \& D.C. Johnson (Eds.) Research Methods in Language Policy and Planning. A Practical Guide. Malden, MA: Wiley-Blackwell. Pp. $33-44$.

Council of Europe (2017). European Charter for Regional or Minority Languages. Sixth report of the Committee of Experts in respect of Sweden.

Council of Europe (2015). Application of the Charter in Sweden, Strasbourg 14 January 2015, $5^{\text {th }}$ monitoring cycle. Report of the Committee of Experts on the Charter.

County Administrative Board of Stockholm \& Sami Parliament (2016). Nationella minoriteter. Minoritetspolitikens utveckling år 2015. [National minorities. The development of minority policy in 2015.] Report.

Dressler, R. (2015). Signgeist: promoting bilingualism through the linguistic landscape of school signage. International Journal of Multilingualism 12(1), 128-145. 
Engman, M. (1995). Finns and Swedes in Finland. In: S. Tägil (Ed.) Ethnicity and nation building in the Nordic world. London: Hurst \& Company, pp. 179-216.

From, T.\& Sahlström, F. (2017). Shared Places, Separate Spaces. Constructing Cultural Spaces through two National Languages in Finland. Scandinavian Journal of Educational Research. 61(4), 465-478.

Gal, S. (2010). Language and political spaces. In: P. Auer \& J.E. Schmidt (Eds.):

Language and space. An International Handbook of Linguistic Variation. Berlin, New York: De Gruyter Mouton. Pp. 33-49.

Gordon, T., Holland, J. \& Lahelma, E. (2000). Making spaces. London: Macmillan.

Gynne, A. \& Bagga-Gupta, S. (2013). Young people's languaging and social positioning. Chaining in "bilingual" educational settings in Sweden. Linguistics And Education, 24 (2013) 479-496.

Hadi-Tabassum, S. (2006). Language, space and power: A critical look at bilingual education. Clevedon: Multilingual matters.

Halonen, M., Ihalainen, P. \& Saarinen, T. (2015). Diverse Discourses in Time and Space: Historical, Discourse Analytical and Ethnographic Approaches to Multisited Language Policy Discourse. In: M. Halonen, P. Ihalainen \& T. Saarinen (Eds.) Language policies in Finland and Sweden. Interdisciplinary and multisited comparisons. Bristol: Multilingual matters. Pp. 3-28.

Heller, M. (2011). Paths to post-nationalism. A critical ethnography of language and identity. New York, Oxford: Oxford University Press.

Heller, M. (2010). The commodification of language. Annual Review of Anthropology. 39: 101-114.

Henning-Lindblom, A. (2012). Vem är jag, vem är vi, vem är vem i vårt land? Kontextens betydelse för gruppidentifikation och stereotypier bland svensk- och finskspråkiga i Finland och Sverige. Helsinki: Forskningsinstitutet, Svenska social- och kommunalhögskolan vid Helsingfors universitet.

Hornberger, N. \& Johnson, D.C. (2010). The ethnography of language policy. In: T. McCarty (Ed.) Ethnography and language policy. New York, NY: Routledge. Pp. 273-289.

Hult, F.M. \& Hornberger, N. (2016). Revisiting Orientations in Language Planning: Problem, Right and Resource as an Analytical Heuristic. Bilingual Review, 33(3), 30-49. 
Hult, F.M., \& Pietikäinen, S. (2014). Shaping discourses of multilingualism through a language ideological debate: The case of Swedish in Finland. Journal of Language and Politics, 13, 1-20

Hult, F.M. (2004). Planning for multilingualism and minority language rights in Sweden. Language Policy, 3(2), 181-201.

Huss, L. (2016). Language Education Policies and the Indigenous and Minority Languages of Northernmost Scandinavia and Finland. In: T. McCarty \& S. May (Eds.) Language Policy and Political Issues in Education. New York: Springer International Publishing. Pp. 367-381.

Ihalainen, P. \& Saarinen, T. (2015). Constructing 'Language' in language policy discourse: Finnish and Swedish legislative processes in the 2000s. In: M. Halonen, P. Ihalainen \& T. Saarinen (Eds.) Language policies in Finland and Sweden. Interdisciplinary and multi-sited comparisons. Bristol: Multilingual matters. Pp. 29-56.

Johnson, D. C. (2011). Critical discourse analysis and the ethnography of language policy. Critical Discourse Studies 8(4). 267-279.

Juva, I. \& Holm, G. (2016). Not All Students Are Equally Equal: Normality as Finnishness. In: K. Kantasalmi \& G. Holm (Eds.) The State, Schooling and Identity. Diversifying Education in Europe. Singapore: Palgrave Macmillan. Pp. $213-232$.

Kajander, K., Alanen, R., Dufva, H., \& Kotkavuori, E. (2015). Kielimuureja vai yhteiseloa: odotuksia ja kokemuksia kahden kielen koulusta. [Language barriers or coexistence: expectations and experiences of a school with two languages]. In T. Jakonen, J. Jalkanen, T. Paakkinen, \& M. Suni (Eds.), Kielen oppimisen virtauksia. Flows of langugage learning (pp. 142-158). Jyväskylä: AFinLA.

Kosunen, S. (2016). Families and the Social Space of School Choice in Urban Finland. Doctoral Dissertation. University of Helsinki.

Lahelma, E. \& Gordon, T. (2010). Comparative and cross-cultural ethnography. In: J. Kauko, R. Rinne \& H. Kynkäänniemi (Eds.) Restructuring the Truth of Schooling - Essays on Discursive Practices in the Sociology of Education. A Festschrift for Hannu Simola. Jyväskylä: Finnish Educational Research Association. Pp. 113-130.

Lainio, J. (2017). Nationella minoritetsspråk i skolan. Förbättrade förutsättningar till 
undervisning och revitalisering [National minority languages in school. Improved prerequisites for instruction and revitalisation]. A report by the Government Offices of Sweden, 2017:91.

Lainio, J. (2015). The art of societal ambivalence: a retrospective view on Swedish language policies for Finnish in Sweden. In: M. Halonen, P. Ihalainen \& T. Saarinen (Eds.) Language policies in Finland and Sweden. Interdisciplinary and multi-sited comparisons. Bristol: Multilingual matters. Pp. 116-145.

Language council of Sweden (2016). Språkrådets omvärldsrapport 2015, Institutet för språk och folkminnen. Retrieved from: http://www.sprakochfolkminnen.se/omoss/publikationer/publikationer-som-pdf/sprakradets-omvarldsrapporter.html.

Latomaa, S. \& Nuolijärvi, P. (2005). The language situation in Finland. In: R. Kaplan \& R. Baldauf (Eds.) Language Planning and Policy in Europe. Clevedon: Multilingual Matters. Pp. 125-232.

Lundahl, L., Erixon Arreman, I., Holm, A-S . \& Lundström, U. (2013). Educational marketization the Swedish way. Education Inquiry, 4(3). 497-517.

McCarty, T.L. (2015). Ethnography in language planning and policy research. In F.M. Hult \& D.C. Johnson (Eds.), Research methods in language policy and planning: A practical guide. Malden, MA: Wiley-Blackwell. Pp. 81-93.

McRae, K. (2007). Toward language equality: four democracies compared. International Journal of the Sociology of Language, 2007(187-188), pp. 13-34.

Milani, T. M. (2007). Voices of Endangerment: A language ideological debate on the Swedish language. In: A. Duchene \& M. Heller (Eds.) Discourses of Endangerment: Ideology and Interest in the Defence of Languages. London, NY: Continuum. Pp. 169-196.

Muhonen, A. (2013). Kenen (ruotsinsuomalaiset) kieli-ideologiat? [Whose (SwedenFinnish) language ideologies?] Kieli, koulutus ja yhteiskunta: Kielikoulutuspolitiikan verkoston verkkolehti. [Language, education and society: The online journal of the Network of Language Education Policies] Retrieved from http://www.kieliverkosto.fi/journals/kieli-koulutus-jayhteiskunta-lokakuu-2013

Rajander, S. (2010). School and choice: An ethnography of a primary school with bilingual classes. Jyväskylä: FERA.

Saarela, J. \& Finnäs, F. (2004). Interethnic wage variation in the Helsinki area. Finnish 
Economic Papers, 17(1), 35-48.

Swedish National Agency for Education (2015). Nationella minoriteter i förskola, förskoleklass och skola [National minorities in daycare, preschool and school]. Available online: https://www.skolverket.se/publikationer?id=1729.

Official Statistics of Finland (OSF): Population structure [e-publication].

ISSN=1797-5395. annual review 2016. Helsinki: Statistics Finland [referred:

19.1.2018]. Available online:

http://www.stat.fi/til/vaerak/2016/01/vaerak_2016_01_2017-09-

22_tie_001_en.html

Shohamy, E. (2006). Language policy: Hidden Agendas and New Approaches.

London, New York: Routledge.

Spolsky, B. (2004). Language policy. Cambridge: Cambridge University Press.

Syrjänen Schaal, K. (2013). Marginalized and Ignored. National minority children's struggle for language rights in Sweden 2013. Retrieved from: http://ungfin.se/wp-content/uploads/2015/08/206507_SvK.pdf.

Palviainen, Å. (2011). Frivillig svenska? Utbildningsrelaterade konsekvenser.

[Voluntary Swedish? Education-related consequenses]. Helsinki: Magma.

Piller, I. (2017). Linguistic diversity and social justice: An introduction to Applied

Sociolinguistics. Oxford: Oxford University Press.

Ruiz, R. (1984). Orientations in language planning. NABE Journal, 8:2, $15-34$.

Tallroth, P. (2012). Strategy for the national languages in Finland. Prime Minister's Office Publications 7/2012. Retrieved from:

http://www .oikeusministerio.fi/material/attachments/om/toiminta/perusoikeudetj ademokratia/6F3CYgZBf/Kansalliskielistrategia_engl.pdf.

Tollefson, J. W. (2013). Language policies in the times of crisis and transformation. In: J. W. Tollefson (Eds.) Language policies in education. Critical issues. New York: Routledge. Pp. 11-34.

Westerholm, A., Lindberg, M. \& Oker-Blom, G. (2014). Elevernas språkliga bakgrund år 2013 [Pupils linguistic background, year 2013]. Presentation in Finlandsvensk grundskolkonferens 3.4.2014. 